\title{
THE LIMITS OF TRANSPARENCY IN ADMINISTRATIVE PROCEEDINGS - THE HUNGARIAN APPROACH ${ }^{1}$
}

\author{
Gergely László Szőke²
}

\begin{abstract}
For both the functioning of the state and in a broader sense, that of society it is a key question to determine who has access to the public data, for what purposes, to what extent and on what conditions. The questions of disposal of, access to and public disclosure related to the data processed by the state concern several fields of law, and the coherency of the legal provisions is far not obvious. The aim of this study is to discuss a few aspects of this comprehensive issue. Since some of the public data are processed in public administration proceedings, the question of how public disclosure is enforced in the specific administrative proceedings, and more specifically, how compliant the Hungarian regulation of the freedom of information is with the right of inspection regarding concrete cases is examined. Although the research is focusing mainly on the Hungarian legislation, the findings of this essay may be also used in the international discourse.
\end{abstract}

\section{Introduction}

Ever since their formation, states have been the largest data controllers, ${ }^{3}$ as the functioning of the state very often appears in practice as an operation performed on the various data, documents or records [2]. It is a key question for both the functioning of the state and in a broader sense, that of society to determine who has access to these, for what purposes, to what extent and on what conditions. There is, however, an important preliminary question too, which is the „level of system” in these data, which can be understood in a concrete, physical sense, i.e. whether the state is aware at all of what data assets it possesses, which public body manages these data, where and how, and how access to and orientation in these (e.g. searching) are ensured in a technical sense. On the other hand, the key question is the ,level of system” in these data in a regulatory sense, i.e. whether the legal classification of the many kinds of data that are processed by the state, the rules that refer to the individual groups of data (e.g. records) are clarified, furthermore, whether the rules of access to these data are well-regulated - and this latter is the key question for the purposes of this paper.

The questions of disposal of, access to and public disclosure related to the data processed by the state concern several fields of law, primarily of course the regulation of data protection and the freedom of information, the various confidentiality rules (especially the regulation of classified data, the rules governing business secrets, as well as the further types of secrets). And the absolutely new field of law, the regulation of the re-use of public sector information (PSI) also should me mentioned, although the role and position of the re-use of PSI is the current scheme of freedom of

\footnotetext{
${ }^{1}$ The paper is based on the results of the OTKA (the Hungarian Scientific Research Fund) research called 'Regulatory Issues of Internet Intermediaries' (No. 116551). The present scientific contribution is also dedicated to the 650th anniversary of the foundation of the University of Pécs, Hungary.

${ }^{2}$ Assistant professor and head of the group of the Group of ICT Law, Department of Administrative Law at the Faculty of Law, University of Pécs. E-mail: szoke.gergely@ajk.pte.hu

${ }^{3}$ It is true that the large online providers are meaningful competitors with regard to personal data these days, as Google, Facebook and other similar pages know at least as much about a user as the state itself.
} 
information is far not obvious [3]. Finally, the public disclosure of the specific public administration procedures, on the other hand, is usually regulated in procedural laws.

These are also hot topics in legal discourse but the research efforts are primarily focused on specific areas. Such research is usually very thorough in these partial areas but there is a scarce number of comprehensive studies in Hungary on the „legal regulation of data” in general and especially, on the legal regulation of what are called public data. ${ }^{4} \mathrm{~A}$ high number of dogmatic issues are unclarified and at many points, it would be justified to analyze some legal institutions, which seem to be different, in relation to each other as well.

The aim of this study is to discuss a few aspects in a declaredly narrow area. Since some of the data of public interest are processed in public administration proceedings, the question of how public disclosure is enforced in the specific administrative proceedings, and more specifically, how compliant the Hungarian regulation of the freedom of information is with the right of inspection regarding concrete cases as stipulated in the Act on the General Rules of Administrative Proceedings and Services (Ket.), ${ }^{5}$ is examined ${ }^{6}$ with an outlook to the new law on public administration procedure, entering into force in $2018 .^{7}$ Although the research is focusing on the Hungarian legislation, the findings of this essay may be also used in the international discourse. ${ }^{8}$

\section{The transparency of the functioning of the state}

Transparency is one of the basic values in the modern democratic societies. Transparency nowadays is put in a broader context: the Open Government approach both emphasise the importance of the transparent operation of the state and the involvement of citizens into public policy decisions. An important element of Open Government initiatives is ensuring access to open, complete and reusable public data. It has to be seen, that Open Data provided by the governments cannot only serve the possibility to control the government by the society but may also foster of creating new (economic and social) values by reusing them in several ways [7].

While referring to the big picture, this essay mainly concentrates on transparency issues. The transparency of state functioning is traditionally meant to be ensured by the freedom of information. Freedom of information is essential for public participation: information about the activities of the government is essential to participate in the democratic process [4]. The question of the freedom of information is sometimes defined as a part or prerequisite of the freedom of expression in international human rights documents. ${ }^{9}$ The Hungarian regulation is different from this and both the protection of personal data and the freedom of information are regulated as fundamental ,information rights", with regard to each other, both on the level of the Fundamental Law and on

\footnotetext{
${ }^{4}$ In this respect, the most comprehensive work is without doubt László MAJTÉNYI’s work, C.f. [8]

${ }^{5}$ Act CXL of 2004 on the General Rules of Administrative Proceedings and Services (Ket.)

${ }^{6}$ This problem was first discussed by me as part of a comprehensive study, in which the relationship between public administration and the media was first brought up in issue 4 of 2015 of the journal Pro Publico Bono (András Bencsik Adrián Fábián - Emese Pál - Gergely László Szőke: A közigazgatás és média kapcsolódási pontjai. This issue is also analyzed by the Commentary on the Public Administration Act [5]

${ }^{7}$ Act. CL of 2016 on the General Public Administration Procedure (Ákr.)

${ }^{8}$ E.g. a Hungarian Case of the ECHR, the case of TASZ vs. Hungary (Judgment by the European Court of Human Rights (Second Section), case of Társaság a Szabadságjogokért v. Hungary, Application no. 37374/05 of 14 April 2009) also concerns this issue, and became an important milestone in the international interpretation of Freedom of Information.

${ }^{9}$ Article 10 of the European Convention on Human Rights is a good example for this.
} 
that of the specific laws. On the level of statutory regulation, this solution appeared as early as in 1992, which at that time qualified as a pioneer solution in Europe [6].

According to Section (2), Article VI of the Fundamental Law of Hungary, „Everyone shall have the right to the protection of his or her personal data, as well as to have access to and disseminate information of public interest." The details of the regulation are found in Act CXII of 2011 on the Right of Informational Self-Determination and on Freedom of Information (hereinafter referred to as: Infotv.).

The concept of 'information of public interest' is defined by the law rather broadly, i. e. „'public information' shall mean any known fact, data and information, other than personal data, that are processed and/or used by any person or body attending to statutory State or municipal government functions or performing other public duties provided for by the relevant legislation (including those data pertaining to the activities of the given person or body), irrespective of the method or format in which it is recorded, and whether autonomous or part of a compilation". ${ }^{10}$ The freedom of information generates a right for the individual, while it imposes an active obligation to ensure the public disclosure of this information for the state. The latter obligation can basically be met in two ways: either by proactively disclosing some data at the start, or by giving access to the applicant if public information is applied for.

Unfortunately, the recent period has clearly seen a tendency of narrowing access to public information via legislation. As examples, we can mention the obligation to provide the name of the data applicant (which, however, does not mean actual identification), which can hardly be justified on a constitutional basis, the emergence of ex-lege secrets (i.e. the legislator qualifies certain data as secrets, via a law, omitting the usual qualification procedure), furthermore, the rules regarding ,account level" control, the significant broadening of cost refunds, as well as the changes related to the so called „data underlying the decisions” - the latter of which we will discuss in detail.

However, the regulation and practice of the freedom of information in Hungary can be described as a legal institution that basically works properly. In this, besides jurisprudence and law enforcement, some players of the media (especially investigative journalists) and quite a number of NGO's focused on this area as data applicants that generate cases also play an important role.

\section{The limits of the transparency of administrative proceedings}

The most exciting issue for the purposes of this study is where the limits of the transparency of public information lie, especially in the individual public administration proceedings, and how coherent the regulation of this area is.

\subsection{The constraints of public disclosure in the Freedom of Information Law}

Starting out from Infotv., we can see several constraints: the protection of personal data, the confidentiality of classified data, the protection of business secrets, and the confidentiality of the special category of data called ,data underlying the decisions". Finally, although it is not directly mentioned in Infotv., certain sectoral and official secrets may also act as further obstacles to transparency.

\footnotetext{
${ }^{10}$ Point 5 , Section 3 of Infotv.
} 
It should be noted that a deed or document may contain a mix of accessible and inaccessible data, and it is not easy to distinguish between these two types of data. According to the provisions set out in Infotv., the data applicant may receive copies of the document or the section of document that contains the data but if the document also contains inaccessible data, this should be made unrecognizable in the copy. ${ }^{11}$ The latter is an operation whose labour cost can be charged to the data applicant as a cost refund, in harmony with the hourly rate of the staff member who actually performs this job. ${ }^{12}$

\subsubsection{Personal data}

By having defined the concept of data of public interest, the legislator made it clear that the accessibility of personal data does not belong to this scope, thus the protection of these enjoys priority, as a general rule. Based on this, those records of public administration which contain personal data do not qualify as data of public interest, neither do those data belong to the latter category which can be related to natural persons in any and all individual cases (administrative proceedings). ${ }^{13}$

\subsubsection{Classified data}

It is also clear and there is also an express reference to it in Infotv. ${ }^{14}$ that access to classified information shall be limited to a predefined scope of persons, which is regulated in detail by a special law. ${ }^{15}$

\subsubsection{Business secrets}

The protection of business secrets also takes priority over the public disclosure of data of public interest, with the exception of a very important and wide group of cases: the data on the utilization of public funds and the use of public property do not qualify as business secrets, i.e. these data shall be transparent. ${ }^{16}$

\subsubsection{Further constraints and secrets}

Infotv. itself sets out provisions on that the access to the data of public interest may be restricted by law, for national defence or national security interests, for the prosecution or prevention of crimes, for environmental protection or nature conservation, central financial or foreign exchange policy interests, with regard to external relations, relations with international organizations, court or administrative proceedings, as well as the right to intellectual property. ${ }^{17}$

In the legal system, there are several different types of sectoral, professional and occupational secrets such as bank secrets, insurance secrets, tax secrets, as well as medical secrets, lawyer's

\footnotetext{
${ }^{11}$ Sections 29(3) and 30(1) of Infotv.

${ }^{12}$ Cf. Point (c) of Section 29(5) of Infotv. with Section 3(2) of government decree No. 301/2016 (IX. 30.) on the extent of the cost refund chargeable for disclosing data of public interest

13 There are, however, several exceptions to this rule as well, the accessibility of certain personal data or records that contain such may be required by law.

${ }^{14}$ Section 27(1) of Infotv.

${ }^{15}$ Act CLV of 2009 on the Protection of Classified Information (Matv.)

${ }^{16}$ Section 27(3) of Infotv.

${ }^{17}$ Section 27(2) of Infotv.
} 
secrets, notary public's secrets, ecclesiastical secrets. These are basically regarded by the legal literature as factors constraining the transparency of data of public interest [8].

\subsubsection{Data underlying the decisions}

However, a part of public administration proceedings does not, or hardly at all affects personal data and/or business secrets, there are even less classified data, so the related regulation in itself does not at all mean that people are not allowed to have access to the details of some cases of public interest (even those in progress) based on the right to the freedom of information. However, in some cases, public disclosure undoubtedly needs to be restricted even beyond this point.

In the interpretation of the right to access to data of public interest, the idea that the confidentiality of certain draft or preparatory documents must be ensured emerged at a rather early stage. In an order adopted by the Constitutional Court as early as 1994, it is stated that ,it is a guaranteed institution of the standards and efficiency of the civil servant's activities that the decision-making of civil servants should be free, informal and free from pressure from the public. This is why the public disclosure of documents refers only to the final versions of the documents and not to the interim, draft materials." 18 The provisions excluding the public disclosure of data prepared for internal use, related to decision-making (e.g. draft materials, memoranda, blueprints, outlines, proposals, correspondence within the organization) ${ }^{19}$ were also published as a specific rule in the law in 1995, which step has since been followed by many amendments and clarifications.

Any data which are developed or recorded in the proceedings that are aimed at decision-making and that underlie the decision in the competence of the body that performs the public task in accordance with the effective regulation are not public for as many as ten years from the date of their generation. However, the head of the public body may allow access to these data, after having considered the weight of public interests in giving or excluding such access. ${ }^{20}$

As long as the decision has already been made, confidentiality can only be maintained in exceptional cases. The effective regulation partially meets this requirement when it stipulates that ,a request for disclosure of information underlying a decision may be rejected after the decision is adopted if the information is retained to support a future decision as well, or if disclosure is likely to jeopardize the legal functioning of the body with public service functions or the discharging of its duties without any undue influence, such as in particular the freedom to express its position during the preliminary stages of the decision-making process on account of which the information was required in the first place." 21

Making sure that ,the information to support a future decision as well” is confidential was included in the law with effect from October 1, 2015, and it may actually involve a significant limitation of the freedom of information - it is especially cynical that the legislator concealed this among the provisions that narrow this confidentiality anyway. In theory, any kind of data may underlie a decision that is to be made later as well, a broader interpretation of this section would lead to the emptying out of the entire right to the freedom of information. The constitutionality of the rule is highly questionable [1] and it clearly goes contrary to the previous practice followed by the

\footnotetext{
${ }^{18}$ Constitutional Court order No. 34/1994 (VI. 24.), translation of the original Hungarian text.

${ }^{19}$ Constitutional Court order No. 12/2004 (IV. 7.)

${ }^{20}$ Section 27(5) of Infotv.

${ }^{21}$ Section 27(6) of Infotv.
} 
Constitutional Court, in which it was mentioned several times that a data request can only be rejected by reference to a specific decision-making process. $^{22}$

The regulation of the data underlying the decision means an automatic restriction of public disclosure on the one hand, in lack of which, an individual decision on the confidentiality of each item of data related to decision-making should be made, in order to ensure the protection of draft materials and the efficiency of the decision-making procedure or the functioning of the body in question", and which ,would mean an intolerable administrative burden" for the affected bodies. ${ }^{23}$ On the other hand, however, the lack of a formal, preliminary classification requirement does not mean that the body concerned should not thoroughly consider the issue. „If the data controller body decides to reject the disclosure of the data of public interest, this [...] should be properly justified in order to ensure that the constitutional requirements are met”, which ,should on the one hand extend to what specific decision to be made in a procedure in progress should be substantiated by the data of public interest to be disclosed, and on the other hand, to what extent the disclosure of the data of public interest affects the adoption of the decision in question". ${ }^{24}$

\subsection{The rules regarding the inspection of documents as set out in Ket. and in Ákr.}

As a starting point, it can be established that the basic principles of Ket. and the Ákr. include neither publicity in general nor the principle of a public hearing ${ }^{25}$ but there is no reference on the level of fundamental principles to the contrary of these, i.e. to the confidentiality of procedural activities and official deeds either. ${ }^{26}$

\subsubsection{Rules of confidentiality}

In relation to the transparency of the documents generated during the procedure and the access to the data included therein, it is Ket.'s Section 17(1) on the protection of privileged data, as well as Section 68 governing the inspection of documents that provide guidance. This means that during the public administration procedure, and under Section 69(6) of Ket., also after the binding closure of the proceedings, access to the documents will primarily be available, besides the clients and the witnesses to third parties: ,third person may be allowed access to documents containing any personal data or privileged information, ${ }^{27}$ if able to substantiate that the inspection of the document is necessary for the enforcement of his right, or for the fulfilment of his obligation conferred upon him by the relevant legislation or an official ruling, and if the legal requirements for access to privileged information are satisfied." 28 The restriction is not limited to privileged information by chance, as the Commentary on the law says that ,the wording of the law is justified by that [if] the documents contain data of public interest or data disclosed for public interests, then any person will be entitled to inspect these documents according to the rules set out in Act CXII of 2011 on the Right of Informational Self-Determination and on Freedom of Information." However, the Commentary on Ket. also narrows down the interpretation of this section without justification when it says that ,in this law, documents that contain personal data (as well as privileged data) are

\footnotetext{
${ }^{22}$ See e.g. the justification of Constitutional Court order No. 21/2013 (VII. 19.)

${ }^{23}$ Constitutional Court order No. 12/2004 (IV. 7.), translation of the original Hungarian text.

${ }^{24}$ Constitutional Court order No. 21/2013 (VII. 19.), translation of the original Hungarian text.

${ }^{25}$ In this paper, the right to a public hearing is not discussed.

${ }^{26}$ Sections 1-8 of Ket., Sections 1-6. of Ákr.

27 According to Section 17(1) privileged information is ,statutory secrets" and „secrets obtained in the course of professional activities".

${ }^{28}$ Section $68(3)$ of Ket.
} 
mentioned but according to the general rule, all official documents are inevitably tied to the clients of the case, so these can be regarded as personal data" [5]. ${ }^{29}$ The problem itself is of a broader scope, as legal entities, economic associations or any other bodies that discharge public duties can be clients as well, in the case of which the personal data are not protected, i.e. in this case only the rules that refer to the privileged data pose restrictions.

According to the provisions set out in Ket., classified data, as well as business, bank, insurance, securities, cash desk secrets, salary secrets, tax secrets, customs secrets, as well as private secrets qualify as statutory secrets, while secrets tied to practicing certain occupations include, especially medical, lawyer's and notary public's secrets, furthermore, the secrets tied to practicing occupations by an ecclesiastical person and the member of an organization pursuing religious activities who performs religious rituals as a profession. ${ }^{30}$ It should be noted that the first one is an itemized list, while the second one quotes examples, i.e. the legal system may contain further rules on secrets that also qualify as privileged data for the purposes of Ket. as well.

The Ákr. contains simplified, but very similar rules. Although the Ákr. does not use the category of "secrets tied to practicing certain occupations", and does not define "statutory secrets", the actual content and interpretation of the provisions regarding the protection of privileged data and access to the documents [Sections 27(2) and 33(3)] are practically the same as in the Ket.

Thus, based on the above sections, the right of inspection of documents is not restricted for third persons (which potentially means anyone) besides personal and privileged data, which, as it turns out from the justification, allows access to the very data of public interest.

Pursuant to Section 17 of Ket., in the case of personal and privileged data, ${ }^{31}$ it is the authority that has to make sure that they are not disclosed to the public and not made familiar to any unauthorized persons. It is also the authority that has to ensure that accessible and inaccessible data are distinguished between, for which, however, a refund of HUF 200 per page can be charged, which is an amount defined in a government decree. ${ }^{32}$

\subsubsection{Data underlying decisions}

In Ket., the confidentiality or transparency of the data underlying the decisions is not discussed in relation to the right of inspection of documents. However, in Point a), Section 69(1), it is specified in detail that draft decisions are not accessible to the public. Section 34(1) of the Ákr. contains the very same restriction. These are absolute prohibitions from which no exemptions can be given by the public body concerned either.

The Commentary on Ket., fundamentally building on the foundations of public administration activities, on the one hand concludes that, since a draft decision or another document that is regarded as one that prepares the final decision (e.g. the relevant memorandum of the executive) are formally not part of the official procedure, they are not given any serial numbers either, the client is most probably not even aware of the existence of such a document, the right of inspection does not

\footnotetext{
${ }^{29}$ Cf. [5], p. 527., translation of the original Hungarian text.

${ }^{30}$ Section 172 of Ket., points g), 1)

${ }^{31}$ It may come up as yet another exciting research issue what exactly the term ,secret protected by law and secret depending on practicing a profession" (jointly: privileged data) of a slightly uncertain content means and whether this rule, which basically limits the transparency of the data of public interest, would stand the test of constitutionality.

32 Sections 68(3) and 69 (3) of Ket.
} 
refer to these documents [5]. On the other hand, the conclusion is that „official documents do not qualify as ones that underlie the decision according to the data protection [and freedom of information] regulation and in the sense of public administration activities, these are real activities rather than actual activities without legal effect" [5]. ${ }^{33}$ In relation to the latter, it should be noted that in the data protection regulation, it is actually not „decision-making documents" but "data underlying the decision" that are discussed, which may, in my view, include all such data of a specific official case which may meaningfully influence the final decision. ${ }^{34}$ It is definitely obvious that the interpretation issues of the data underlying the decisions are by far not uniform and it can also be established that the interpretation used by the acting public administration body has a rather wide space for manoeuvre in judging this, both as consequence of the system of Infotv. and that of Ket. (and the future Ákr.).

\section{Conclusions}

The question posed by the research was to what extent the regulation of the freedom of information was in compliance with the Rules of Administrative Proceedings (Ket.) regarding the right of inspection of and access to documents in concrete cases. Based on the above, it can be concluded that the rules of Infotv. and Ket. on the right of inspection of documents are roughly in harmony with each other, which is partly due to a Ket. amendment of 2008, which was partially aimed at this, and which is rather fortunate because there is nothing to justify that the rules governing the documents (data) under the effect of Ket. are different from those other data of public interest which are not subject to Ket.

This, however, does not mean that no further research is necessary on this subject, or that the legislator has nothing to do any more. The situation is that the roughly coherent regulation is by far not self-apparent at first sight - this is why this research was conducted at all -, it would make sense to add a few clarifying rules. On the one hand, Infotv. should be supplemented by references to the sectoral and occupational secrets. Furthermore, although the justification of Ket. contains a reference to the right of access to data of public interest, it would also be worthwhile to make this correlation clear in the very text of the law as well. Also, there is a narrow area where it is clear that there is no harmony: these are the rules of cost refunds related to making inaccessible data unrecognizable, which will lead to a different result if one wishes to access an item of data in the context of requesting data of public interest and if one wishes to use the right of inspection set out in Ket.. It is true that so far, this has not caused any problem whatsoever, according to the relevant legal practice. However, some other, yet unclarified questions of interpretation may arise in relation to some further details, for example, when determining the nature of certain documents as ones that underlie or prepare the decisions, with regard to the limited right of inspection ,for a reasonable private interest" upon the client's request [Section 69(2) of Ket.], or regarding the duration of the limitation of access.

All in all, I agree with a conclusion from the Commentary that ,if one wishes to inspect the documents, or request a copy, then a rather considerable analysis of content will become necessary

\footnotetext{
${ }^{33}$ Cf. [5], p. 541., translation of the original Hungarian text.

34 See also, the wording of Bianka Maksó, who says that ,all such documents which are generated during the proceedings or decision-making process of any bodies or persons which or who fulfil state, local government, public administration or other public responsibilities, and the use of which contributes to the lawfulness, professionalism and effectiveness of the final decision, may be listed in this category" (translation of the original Hungarian text) [9].
} 
for even deciding what procedure the request in question should belong to" [5]. ${ }^{35}$ and also, this especially holds true for finding out whether one is talking about accessible or inaccessible data.

This essay has focused on and showed the provisions of the Ket. in detail, but it seems, that the new regulation of the public administration procedure, the Ákr. contains very similar provisions, so no significant changes can be expected, and these consequences are going to be true in the new legal environment, too.

The lessons of this analysis about Hungary may be useful also for other legislations. It is important, that Freedom of Information Law should be in compliance with many other fields of law, namely with the procedure of public administration, otherwise specific regulation may deteriorate the right to access to information, even if freedom of information is regarded as a fundamental right.

Besides these findings, this research also brings up quite a number of other relevant questions which refer to the confidentiality regulation. How compliant are the individual types of secrets regulated by the Hungarian law with each other? What does the difference between business secrets, as well as sectoral and official secrets lie in? Would the rules governing these types of secrets stand the test of the restriction of the freedom of information as a fundamental constitutional right? And especially, how do the sectoral and official secrets relate to the public disclosure of data of public interest when these affect the use of public funds or the utilization of public property? These are the many questions which can only be answered by the findings of further research efforts.

\section{References}

[1] ASBÓTH, M.: A közérdekű adatok nyilvánosságának legújabb jogszabályváltozása [The Latest Changes in the Law on the Public Disclosure of Data of Public Interest], in: M. Fazekas (ed.), Gazdaság és közigazgatás: tanulmányok Ficzere Lajos tiszteletére [Economy and Public Administration: Studies in Honor of Lajos Ficzere], ELTE Eötvös Kiadó, Budapest 2015.

[2] BALOGH, ZS. GY.: Jogi informatika [Legal Informatics], Dialóg Campus, Budapest-Pécs, 1998.

[3] BALTHASAR, A.: Right of Access to Information? Prolegomena to a rising issue with due consideration of the legal nature of information, in: A. Balthasar and M. Sully (eds.), Public Sector Information - Open Data -. What is fair: Free Access or Fees? Facultas Verlags- und Buchhandels AG, Vienna 2014.

[4] BANISAR, D.: Freedom of Information Around the World 2006., Privacy International 2006. http://www.humanrightsinitiative.org/programs/ai/rti/international/laws_papers/intl/global_foi _survey_2006.pdf (accessed 12 December 2016)

[5] BARABÁS, B., BARANYI, A. and KOVÁCS, A. GY.: (eds.), Nagykommentár a közigazgatási eljárási törvényhez [Commentary on the Public Administration Act], Complex, Budapest, 2013.

\footnotetext{
${ }^{35}$ Cf. [5], p. 534., translation of the original Hungarian text.
} 
[6] DIX, A.: The influence of Hungarian Freedom of Information legislation abroad - The Brandenburg example and experience, in: L. MAJTÉNYI (ed.), Az odaátra nyíló ajtó. The Door onto the Other Side, Adatvédelmi Biztos Irodája, Budapest 2001.

[7] GURIN, J.: Open Data Now, McGraw-Hill Education, 2014.

[8] MAJTÉNYI, L.: Információs szabadságok - adatvédelem és a közérdekű adatok nyilvánossága (Information Rights - Data Protection and Freedom of Information), Complex, Budapest, 2006.

[9] MAKSÓ, B.: Kivert biztosíték? - Az információszabadság a döntés megalapozását szolgáló adatok korlátozott nyilvánosságának tükrében [A Blown Fuse? - The Freedom of Information in view of the Limited Public Disclosure of the Data Underlying the Decisions].

Infokommunikáció és jog, No. 5-6, 2012. 